\title{
Gaya Kepemimpinan dan Karekteristik Pemimpin yang Efektif
}

\author{
Husen Waedoloh, Hieronymus Purwanta, Suryo Ediyono
}

Universitas Sebelas Maret

husen_123@student.uns.ac.id

\section{Article History}

received $1 / 9 / 2021$

\begin{abstract}
Leaders have their own unique and distinctive traits, habits, temperament, character, and personality so that their behavior and style can be distinguished from others. This style or lifestyle will color his behavior and type of leadership. Leadership refers to someone influencing the behavior of others for a purpose. With power, leaders can influence the behavior of their subordinates. This study aimed to determine the characteristics of leaders and effective leadership styles. Ideal leadership is a dream or a hope for every organization. There are 8 (eight) ideal leadership characteristics, namely: honest, intelligent, responsible, visionary, correct, disciplined behavior, initiative and, direct. Character is the key to an organization's success. An organization will move forward or backward depending on the leader. Because the leader is the one who directs and determines the organizational objectives to be achieved. The method used in this research is the study of literature or library research and by conducting observational studies from previous studies. Library research, Researchers study and collect data through several kinds of literature and reading sources that support and are relevant to research. In this case, literature research is carried out through books, magazines, internet.
\end{abstract}

Keywords: Leadership Style, Leader Characteristics

\begin{abstract}
Abstrak
Pemimpin memiliki sifat, kebiasaan, perangai, watak dan kepribadian yang unik dan khas, sehingga perilaku dan gayanya membedakan dirinya dengan orang lain. Gaya atau style hidup ini pasti akan mewarnai perilaku dan tipe kepemimpinannya. Kepemimpinan (leadership) berkenaan dengan seseorang yang mempengaruhi perilaku orang lain untuk suatu tujuan. Dengan kekuasaan, pemimpin dapat mempengaruhi perilaku bawahannya. Tujuan dari penelitian ini adalah untuk mengetahui karakteristik pemimpin dan gaya kepemimpinan yang efektif. Kepemimpinan yang ideal merupakan impian atau harapan bagi setiap organisasi. Ada 8 (delapan) karakteristik kepemimpinan yang ideal, yaitu: jujur, cerdas, bertanggung jawab, visioner, adil, perilaku disiplin, inisiatif dan lugas. Karakter merupakan kunci keberhasilan suatu organisasi. Suatu organisasi akan maju atau mundur tergantung dari pemimpinnya. Karena pemimpinlah yang mengarahkan dan menentukan tujuan organisasi yang ingin dicapai. Metode yang digunakan dalam penelitian ini adalah studi literatur atau studi kepustakaan dan dengan melakukan studi pengamatan dari penelitian-penelitian sebelumnya. Penelitian kepustakaan (library research). Peneliti mempelajari dan mengumpulkan data melalui beberapa literatur dan sumber bacaan yang mendukung dan relevan dengan penelitian. Dalam hal ini, penelitian kepustakaan dilakukan melalui buku, majalah, internet dan sebagainya.
\end{abstract}

Kata kunci: Gaya Kepemimpinan , Karekteristik Pemimpin

Social, Humanities, and Education Studies (SHEs): Conference Series https://jurnal.uns.ac.id/shes

p-ISSN 2620-9284

e-ISSN 2620-9292 


\section{PENDAHULUAN}

Kepemimpinan merupakan peran penting dalam organisasi. Berhasil atau tidaknya suatu organisasi ditentukan oleh sumber daya yang ada dalam organisasi tersebut. Selain itu, faktor yang sangat penting adalah faktor kepemimpinan. Peran utama dari faktor kepemimpinan adalah mempengaruhi orang lain untuk mencapai tujuan yang telah ditentukan. Pengembangan organisasi adalah suatu kegiatan untuk melakukan perubahan secara terencana yang meliputi diagnosa sistematis organisasi. Seorang pemimpin harus berperan aktif dalam mengelola pelaksanaan kegiatan usaha pengembangan organisasi.

Semua pekerjaan, besar atau kecil, harus dilakukan oleh orang yang tepat, istilah populernya adalah "the right man in the right place". Rasulullah SAW beberapa abad yang lalu telah memperingatkan "jika suatu urusan diserahkan kepada seseorang yang bukan ahlinya (tidak memiliki kapasitas untuk melaksanakannya), maka tunggulah waktu kehancurannya" (H.R. Bukhari bab IImu).

Kepemimpinan berfungsi sebagai tindakan yang dilakukan oleh pemimpin dalam upaya menggerakkan anggota agar mau mewujudkan program kerja yang telah disepakati bersama. Keberhasilan suatu organisasi tergantung pada kemampuan para pemimpinnya untuk menjalankan fungsi kepemimpinannya dengan baik sebagai seorang pemimpin.

Masalah kepemimpinan tidak dapat dipisahkan dari pembahasan tentang manajemen. Sementara itu, dijelaskan pula bahwa pemimpin adalah seorang gembala, dan setiap penggembala akan ditanya tentang perilaku penggembalaannya. Keberhasilan atau kegagalan suatu organisasi sangat ditentukan oleh kepemimpinan ini. Keberhasilan kegiatan usaha pengembangan organisasi sangat ditentukan oleh kekuatan pimpinan atau manajer dan komitmen pimpinan puncak organisasi.

Kepemimpinan merupakan sesuatu yang harus dimiliki oleh pemimpin organisasi. Ungkapan yang mengatakan bahwa pemimpin bertanggung jawab atas hasil pelaksanaan suatu pekerjaan merupakan ungkapan yang memposisikan pemimpin sebagai posisi terpenting dalam organisasi. Dalam kehidupan berorganisasi, gaya kepemimpinan seorang pemimpin merupakan hal yang penting untuk diperhatikan.

Jadi, pemimpin harus dapat memahami perilaku anggotanya dalam organisasi yang dipimpinnya untuk dapat menemukan gaya kepemimpinan yang tepat bagi organisasinya. Gaya kepemimpinan mengacu pada struktur kebutuhan pemimpin yang memotivasi perilaku dalam berbagai situasi. Seorang pemimpin yang ideal haruslah seseorang yang memiliki kemampuan dan profesionalisme untuk memimpin dengan manajemen dan sistem yang baik.

Sesungguhnya, pemimpin dan kepemimpinan merupakan suatu kesatuan kata yang tidak dapat dipisahkan secara struktural maupun fungsional. Seperti organisasi, dan juga terdapat banyak pengertian-pengertian mengenai pemimpin dan kepemimpinan. Berdasarkan penjelasan tersebut di atas, dengan jelas penulis memaparkan pentingnya gaya kepemimpinan dan kerekristik pemimpin dalam mengatur organisasi. Untuk itu makalah ini ingin menjawab pertanyaan apa gaya kepemimpinan dan karekteristik pemimpin yang efektif

\section{Definisi Pemimpin dan Kepemimpinan}

\section{KAJIAN TEORI}

Pemimpin mempunyai macam-macam pengertian dari para ahli. Berikut ini terdapat beberapa definisi tentang pemimpin diantarnya:

Menurut Amirullah (2015) dalam bahasa Indonesia "pemimpin sering disebut penghulu, pemuka, pelopor, Pembina, ketua, kepala, penuntun, raja, tua-tua dan sebagainya. Istilah pemimpin, kepemimpinan dan memimpin pada mulanya berasal dari kata dasar yang sama "pimpin". Namun demikian ketiganya digunakan dalam konteks yang 
berbeda. Pemimpin adalah suatu peran dalam sistem tertentu; karenanya seseorang dalam peran formal belum tentu memiliki keterampilan kepemimpinan dan belum tentu mampu memimpim.

Menurut Hasbuan (2011) Pemimpin adalah seseorang yang mempergunakan wewenang dan kepemimpinannya untuk mengarahkan orang lain serta bertanggung jawab atas pekerjaan orang tersebut dalam mencapaikan suatu tujuan. Sedangkan menurut Kartono (2010) Pemimpin adalah seorang pribadi yang memiliki kecakapan dan kelebihan, khususnya kecakapan dan kelebihan di satu bidang sehingga dia mampu mempengaruhi orang lain untuk bersama-sama melakukan aktivitas-aktivitas tertentu demi pencapaian satu atau beberapa tujuan. (Yuliana \& Widayati, 2018)

Definisi kepemimpinan dari para ahli adalah sebagai berikut :

Kepemimpinan berasal dari kata pimpin, menurut Veihzal Rivai (2003) Definisi kepemimpinan secara luas adalah meliputi proses mempengaruhi dalam menentukan tujuan organisasi, motivasi perilaku bawahan untuk mencapai tujuan, mempengaruhi untuk memperbaiki kolompok dan budayanya. Selain itu juga mempengaruhi interprestasi mengenai peristiwa-peristiwa para bawahannya, pengorganisasian dan aktivitas-aktivitas untuk mencapai sasaran, memelihara hubungan kerjasama dan kerja kelompok, perolehan dukungan dan kerjasama dari orang-orang di luar kelompok atau organisasi. Kepemimpinan hanyalah sebuah alat, sarana atau proses untuk membujuk orang agar bersedia melakukan sesuatu secara suka rela atau sukacita.

Ada beberapa factor yang dapat mengerakkan orang yaitu karena ancaman, penghargaan, otoritas dan bujukan. Kepemimpinan adalah proses mengarahkan dan mempengaruhi aktivitas-aktivitas yang ada hubungannya dengan pekerjaan para anggota kelompok. Tiga implikasi penting yang terkandung dalam hal ini yaitu: (1) kepemimpinan itu melibatkan orang lain baik itu bawahan ataupun pengikut, (2) kepemimpinan melibatkan pendistribusian kekuasaan antara pemimpin dan anggota kelompok secara seimbang, karena anggota kelompok bukanlah tanpa daya, (3) adanya kemampuan untuk menggunakan berbagai bentuk kekuasaan yang berbedabeda untuk mempengaruhi tingkah laku bawahannya dengan berbagai cara.

Konsep kepemimpinan erat sekali hubungan dengan kekuasaan pemimpin dalam memporoleh alat untuk mempengaruhi perilaku para pengikutnya. Terdapat beberapa sumber dan bentuk kekuasaan paksaan, legistimasi, keahlian, penghargaan, referensi, informasi dan hubungan. Pada dasarnya kemampuan untuk mempengaruhi orang atau suatu kelompok untuk mencapai tujuan tersebut ada unsur kekuasaan. Kekuasaan tak lain adalah kemampuan untuk mempengaruhi orang lain untuk mau melakukan apa yang diinginkan oleh pihak lainnya.

Praktik kepemimpinan berkaitan dengan mempengaruhi tingkah laku dan perasaan orang lain baik secara individual maupun kelompok dalam arahan tertentu, sehingga melalui kepemimpinan merujuk pada proses untuk membantu mengarahkan dan memobilisasi orang atau ide-idenya. Sedangkan menurut Kartono (2010) Kepemimpinan merupakan salah satu relasi dan pengaruh antara pemimpin dengan yang dipimpin. Kepemimpinan tersebut muncul dan berkembang sebagai hasil dari interaksi otomatis antara pemimpin dengan orang-orang yang dipimpin.

\section{Fungsi Pemimpin \& Kepemimpinan}

Pemimpin sesuai dengan perannya, memiliki fungsi utama yang harus dipahami secara mendalam terhadap fungsi yang berhubungan denagan tugas atau bahkan memecahkan masalah. Keutuhan dan kekompakan kelompok atau sosial merupakan fungsi selanjutnya yang ada pada umumnya sering diabaikan. Leadership style (gaya kepemimpinan) yang menggambarkan tentang pola tingkah laku pemimpin dalam proses pengarahan juga sebagai salah satu akan mempengaruhi pekerja yang ada. Menurut Kouzes dan Posner, Keberhasilan seorang pemimpin harus dapat memenuhi kaidah sebagai berikut: makna/keterpagilan; visi/arah yang jelas; kemampuan 
memeriksa dan menata pola kerja yang sudah ada; kemampuan mengembangkan orang; dan kemampuan mengangkat hati mereka. Sebagai pemimpin, berarti juga melaksanakan fungsi melayani dengan pengharapan sebagai leading up artinya memimpin ke atas dan berkembang, leading across yang berarti pemimpin juga memimpin kesamping yang artinya belajar dari orang lain, leading down atau memimpin ke bawah yang maknanya mengembangkan orang-orang di bawah, dan lainnya adalah leading inside. (Jatmiko, 2013).

Pemimpin memegang fungsi penting dalam sebuah organisasi. Menurut Sondang P. Siagian (2003) Kerana kemampuan mengambil keputusan adalah kretaria utama dalam menilai efektivitas kepemimpinan seseorang, berarti ada kritaria lain yang dapat dan biasanya digunakan. Berbagai kritaria itu berkisar pada kemampuan seorang pemimpin menjalankan berbagai fungsi-fungsi kepemimpinan. 5 (Lima) fungsi kepemimpinan yang dibahas secara singkat adalah sebagai berikut:

a. Pemimpin selaku penentu arah yang akan ditempuh dalam usaha mencapai tujuan,

b. Wakil dan juru bicara organisasi dalam hubungan dengan pihak-pihak diluar organisasi,

c. Pemimpin selaku komunikator yang efektif,

d. Mediator yang handal, khususnya dalam hubungan ke dalam, terutama dalam menangani situasi konflik,

e. Pimpinan selaku intergrator yang efektif, rasional, objektif dan netral.

\section{Pengertian Gaya-gaya Kepemimpinan}

Gaya kepemimpinan adalah sekumpulan ciri yang diguanakan pimpinan untuk mempengaruhi bawahan agar sasaran organisasi tercapai. Dalam pengertian lain gaya kepemimpinan adalah pola perilaku, strategi ataupun konsep yang sering diterapkan oleh seorang pemimpin. Gaya kepemimpinan atau tipe kepemimpinan yang menunjukan secara langsung dan tidak langsung tentang keyakinan seorang pemimpin terhadap kemampuan bawahannya. Artinya, gaya kepemimpinan ialah perilaku dan strategi, sebagai hasil kombinasi keterampilan, sifat, sikap yang sering diterapkan seorang pemimpin ketika ia mencoba mempengaruhi bawahannya.

Adapun definisi gaya kepemimpinan menurut Stoner (1996) menyatakan bahwa gaya kepemimpinan adalah berbagai pola tingkah laku yang disukai oleh pemimpin dalam proses mengarahkan dan mempengaruhi pekerja. Sedangkan menurut Rivai (2004) menyatakan gaya kepemimpinan adalah sekumpulan ciri yang digunakan pimpinan untuk memegaruhi bawahan agar sasaran organisasi tercapai atau dapat pula dikatakan bahwa gaya kepemimpinan adalah pola perilaku dan strategi yang disukai dan sering diterapkan ole seorang pemimpin.

\section{METODE}

Penelitian ini dilakukan dengan menggunakan pendekatan deskriptif kualitatif yaitu penelitian yang berusaha memberikan suatu penjelasan secara cermat tentang beberapa situasi sosial yang berupa uraian kelimat dan datanya tidak berhubungan dengan angka-angka (Arikunto, 2006). Metode yang digunakan dalam penelitian ini adalah studi literatur atau studi kepustakaan dan dengan melakukan studi pengamatan dari penelitian-penelitian sebelumnya. Penelitian perpustakaan (library research) Peneliti mempelajari dan mengumpulkan data melalui beberapa literatur dan sumber bacaan yang mendukung dan relevan dengan penelitian. Dalam hal ini, penelitian kepustakaan dilakukan melalui buku, majalah, internet dan sebagainya. 


\section{HASIL DAN PEMBAHASAN}

Pemimpin dalam menentukan gaya kepemimpinannya wajib mampu menyesuaikan dengan situasi, kondisi pada waktu dan tempat tertentu. Pemimpinpemimpin yang berhasil itu adalah mereka bisa menyesuaikan perilaku dirinya sesuai dengan tuntutan dari keunikan lingkungannya. Kepemimpinan yang efektif sangat tergantung akan gaya perilaku yang disesuaikan dengan situasi dan kondisi tertentu (Grensing, 2008).

Gaya kepemimpinan merupakan norma perilaku yang digunakan oleh seseorang pada saat orang tersebut mencoba mempengaruhi perilaku orang lain. Menurut Handoko (2000:306) gaya kepemimpinan yang ideal adalah gaya yang secara aktif melibatkan bawahan dalam penetapan tujuan dengan menggunakan teknik-teknik manajemen partisipatif dan memusatkan perhatian baik terhadap karyawan dan tugas. (Hakim \& Yahya, 2014)

Para ahli dalam berbagai bidang telah banyak melakukan penelitian terhadap gaya dalam melaksanakan kepemimpinan. Meskipun istilah yang dipergunakan tidak sama, akan tetapi maksudnya sama saja. Frankyn dalam Effendy (1993) mengemukakan ada tiga gaya pokok kepemimpinan yaitu gaya kepemimpinan otoriter (outoctatic/authoritarian leadership), kepemimpinan demokratis (democratic/participative leadership), dan kepemimpinan yang bebas (free-reun/laissez faire leadership).

a. Kepemimpinan otoriter adalah kepemimpinan yang didasarkan pada kekuasaan absolut. Seorang pemimpin otoriter mengarahkan perilaku pengikutnya dengan mengarahkan mereka pada tujuan yang telah ditentukan. Semua keputusan ada di tangan pemimpin otoriter, yang dianggap oleh orang lain dan yang menganggap dirinya lebih tahu daripada orang lain. Semua keputusannya dianggap sah, dan para pengikutnya menerima tanpa pertanyaan. Pemimpin otoriter ini dianggap bahwa sebagai manusia super.

b. Kepemimpinan demokratis adalah kepemimpinan yang berdasarkan demokrasi. Yang penting di sini, bukanlah pemimpin yang dipilih secara demokratis oleh para pengikutnya, melainkan cara ia menjalankan kepemimpinannya secara demokratis. Pemimpin bertindak sedemikian rupa sehingga suatu keputusan merupakan keputusan bersama semua anggota kelompok. Setiap anggota kelompok harus tunduk pada keputusan mayoritas anggota kelompok. Fungsi pemimpin di sini adalah untuk membimbing dan mengkoordinasikan proses pengambilan keputusan. Meskipun dia memberikan ketentuan, ketentuannya adalah bagaimana anggota kelompok dapat berpikir dan mengambil keputusan, bukan apa yang harus mereka pikirkan dan putuskan. Di sini tidak ada yang lebih super dari siapa pun. Setiap orang dari setiap anggota kelompok adalah sama nilainya, oleh karena itu setiap orang memiliki hak yang sama untuk mengambil keputusan mengenai hidupnya.

c. Kepemimpinan bebas adalah pemimpin yang menjalankan perannya secara pasif. Dia menyerahkan segala upaya untuk menentukan tujuan dan kegiatannya sepenuhnya kepada anggota kelompok. Dia hanya menyerahkan bahan dan alat yang dibutuhkan untuk pekerjaan itu. Dia tidak mengambil inisiatif apa pun, meskipun dia berada di tengah-tengah kelompok. (Dirham, 2019)

Sedangkan menurut Siagian (2008), ada 5 (lima) gaya kepemimpinan yang dapat digunakan seorang pemimpin, ialah:

a. Tipe Otokratik.

b. Tipe Paternalistik.

c. Tipe Kharismatik. 


\section{d. Tipe Laissez-faire. \\ e. Tipe Demokratik.}

Berdasarkan percobaan pelaksanaan kepemimpinan, untuk manajemen pada umumnya, dan untuk kegiatan human relation dan public relations pada khususnya, kepemimpinan demokratis adalah yang terbaik. Dalam kepemimpinan demokratis, pemimpin berpartisipasi dan berinteraksi dengan anggota kelompoknya. Pemimpin berinisiatif, namun dalam pelaksanaannya melibatkan anggotanya untuk berdiskusi bersama terlebih dahulu. Bawahannya dimintai pendapatnya, sehingga keputusan yang dihasilkan merupakan hasil pemikiran bersama. Keputusan yang diambil dengan cara ini akan menyebabkan setiap anggota kelompok merasa dihargai, bertanggung jawab atas keputusan tersebut dan bersedia melaksanakannya dengan sepenuh hati. Dalam keadaan darurat, situasi kritis menghadapi bencana seperti kebakaran dan demonstrasi, kepemimpinan otoriter untuk sementara dapat diterapkan. Namun, ketika situasi kembali normal, kepemimpinan semacam ini harus kembali ke kepemimpinan yang demokratis.

Kepemimpinan dapat dilihat sebagai instrumen dalam upaya mempengaruhi dan mengendalikan seseorang atau sekelompok orang untuk bekerja sama dalam mencapai tujuan tertentu. Selain itu, kepemimpinan sangat diperlukan dalam menggerakkan kegiatan suatu organisasi. Jadi, kepemimpinan ini merupakan salah satu faktor yang paling penting dan menentukan dalam suatu organisasi.

Suatu organisasi akan berjalan dengan baik jika pimpinan memiliki rasa tanggung jawab yang tinggi. Rasa tanggung jawab seorang pemimpin merupakan salah satu ciri kepemimpinan yang ideal. Namun yang tidak kalah pentingnya, seorang pemimpin harus cerdas, agar selalu dapat memilih dan memecahkan suatu masalah yang dihadapi dalam organisasi yang dipimpinnya.

Untuk lebih jelasnya, penulis akan membahas tentang karekter kepemimpinan yang ideal. Kepemimpinan yang ideal sedikitnya memiliki 8 (delapan) karekter, yaitu : a. Jujur

Nilai kejujuran bagi seorang pemimpin merupakan salah satu nilai dasar yang harus atau bahkan harus dimiliki seorang pemimpin. Seorang pemimpin yang jujur sangat menghargai apa yang telah dicapainya itu berasal dari orang-orang yang mempekerjakannya, jadi seorang pemimpin sejati harus selalu mengingatnya dan menjadikannya sebagai falsafah hidupnya. Pemimpin sejati adalah pemimpin yang selalu dalam mengatur negara akan selalu mengunjungi kebenaran (will to truth) dan tidak mengunjungi kekuasaan (will to power), sehingga ia tidak mengalami apa yang disebut dengan orientasi perpecahan, yaitu tidak menyatu. antara kata dan tindakan. Biasanya seorang pemimpin sejati dalam menjalankan tugasnya selalu dilandasi dengan keikhlasan dan kemauan dari yang berkuasa. Jika falsafah Jawa dikenal, ada istilah atau moto "sepi ing pamrih rame ing gawe".

b. Cerdas

Kecerdasan adalah sesuatu yang dapat dijadikan modal dasar. Karena pemimpin yang cerdas adalah orang yang mampu menghargai puncak kehidupan, dan dia akan selalu mengunjungi kebenaran (will to truth) dan tidak mengunjungi kekuasaan (will to power) sehingga dia tidak mengalami apa yang disebut dengan orientasi perpecahan. Itu bukan penyatuan antara ucapan dan tindakan. Jika hal ini terjadi, ia masih dalam kategori yang disebut Francis Fukuyama sebagai manusia pertama, manusia yang hanya menjadi pemandu otoriter, yang berbeda dengan kategori manusia terakhir yang sudah mementingkan martabat dan harga diri. Pemimpin seperti ini hanya bertahan sebentar, dan hal ini telah dibuktikan oleh beberapa peneliti. Seperti hasil penelitian Michal Keren dan Moshe Bzuonowski yang menyatakan bahwa bekal utama bagi pemimpin untuk "menguasai publik" adalah popularitas dan intelektualitas. Namun jika pemimpin ingin bertahan lama, 
maka kecerdasan yang harus dikedepankan, bukan popularitas semata. Demikian juga Jean Laponce berpendapat bahwa pemimpin yang populer berkat ide-ide cemerlang dan cerdasnya akan bertahan lebih lama jika dibandingkan dengan pemimpin yang hanya mengandalkan popularitas dan retorika belaka. Pemimpin yang cerdas biasanya memiliki perilaku kritis dalam menanggapi beberapa sinyal.

c. Bertanggung jawab

Pemimpin yang bertanggung jawab adalah pemimpin yang menjalankan tugasnya, selalu memiliki rasa tanggung jawab. Sehingga pemimpin dalam menjalankan tugas dan tanggung jawabnya dilaksanakan dengan sungguh-sungguh dan tidak dilakukan dengan asal-asalan. Pemerintahan yang bijaksana memiliki makna yang lebih dalam, yaitu tidak hanya mengandalkan legalitas hukum (otoritas) untuk menjalankan administrasi publik, tetapi juga berusaha menumbuhkan rasa memiliki (sense of belonging) dan rasa tanggung jawab (sense of responsibility) masyarakat terhadap proses administrasi publik dan hasil pembangunan yang dicapai (Karhi Nisjar S; 1993). Dalam demokrasi, tanggung jawab menjadi sesuatu yang urgen, yaitu setiap pemegang jabatan yang dipilih oleh rakyat harus dapat mempertanggungjawabkan kebijakan yang diinginkan dan telah ditempuhnya. Tidak hanya itu, ia juga harus bertanggung jawab atas ucapan atau perkataannya. Dan yang tidak kalah pentingnya adalah perilaku dalam kehidupan yang telah, sedang dan yang akan dijalaninya. Tanggung jawab tidak hanya menyangkut dirinya sendiri, tetapi juga menyangkut keluarganya dalam arti luas. Yaitu perilaku istri dan anakanaknya, serta kerabatnya, terutama yang berkaitan dengan jabatannya. Dalam konteks ini, si pemegang jabatan harus bersedia menghadapi apa yang disebut sebagai "public scrutiny", terutama yang dilakukan oleh media massa yang ada. (Joko, 2001)

d. Visioner

Tugas seorang pemimpin adalah membawa orang-orang yang dipimpinnya kepada suatu tujuan di masa depan. Seorang pemimpin tidak akan dapat menjalankan tugasnya, ia sendiri tidak dapat memiliki gambaran yang jelas tentang masa depan seperti apa yang ingin ia capai dengan dirinya dan semua orang yang dipimpinnya. Hal ini tidak hanya berlaku bagi seorang pemimpin organisasi yang berorientasi pada keuntungan tetapi juga berlaku untuk semua jenis kepemimpinan organisasi non profit atau publik. Seseorang yang memiliki visi jauh ke depan tidak akan bisa menjadi pemimpin yang sukses jika dia tidak dapat menyakinkan pengikutnya untuk mau berubah ke arah yang dicita-citakannya. Seseorang yang memiliki visi, memiliki kemampuan untuk mengomunikasikan visinya, memotivasi orang-orang yang dipimpinnya untuk mau bekerja sama menuju kondisi yang dicitacitakannya, antara lain dengan memperhatikan, mau mendengarkan dan memberikan kepercayaan dan kesempatan kepada orang-orang yang bekerja dengannya. (Makhfudz, 2011)

e. Adil

Seorang pemimpin yang ideal harus bertindak adil, sehingga mampu memperlakukan anggotanya dengan perlakuan yang sama sesuai dengan tugas dan bidangnya masing-masing. Demikian juga seorang pemimpin tidak berpihak pada salah satu, melainkan semua anggota.

f. Disiplin Perilaku

Sebagai pemimpin, sudah menjadi kewajiban memiliki sikap yang berlandasan pada standar moral yang tinggi yaitu berbudi luhur (character building), selain itu seorang pemimpin harus mampu menguasai kemampuan yang tinggi untuk mewujudkan visinya yang dilandasi oleh nilai-nilai luhur perilakunya dan keberanian untuk mengambil keputusan. Kemampuan tersebut harus didukung oleh konpetensi yang tinggi menyangkut pengetahuan (knowledge), keterampilan (skill) maupun kematangan psikologis. Agar pemimpin memiliki unsur-unsur tersebut harus 
memiliki sifat disiplin yang tercamin dalam sikapnya yang selalu menjaga ketepatan perilaku, misalnya seperti tepat waktu dalam melaksanakan sesuatu yang telah diperjanjikan, satunya kata dengan perbuatan "walk the talk", perilaku konsisten dalam menimba ilmu, melakukan kewajiban spiritualnya secara konsisten dan lainlainnya. Disiplin disini adalah suatu sikap perilaku yang erat hubungannya dengan sikap yang langsung dapat dirasakan dan dimengerti oleh orang lain. Seperti halnya yang memang sesuai dengan petunjuk Sang pencipta, sesuai dengan profosi seseorang missal berprofesi sebagai seorang banker harus memiliki perilaku yang ramah terhadap setiap nasabah dan supel dalam pergaulannya, sehingga dapat mendukung kariernya dalam mengembangkan usahanya dan jauh dari perilaku yang tercala seperti menghidupkan perilaku yang mewajibkan pada setiap stafnya atau bawahannya harus setor/menyerahkan upeti pada atasannya contoh mengharuskan pada nasabah setiap kredit/pinjaman akan keluarkan harus melakukan gratifikasi sebagai syarat keluarnya kredit (pinjaman). Perilaku berikutnya adalah suka menghormati orang lain, baik nasabah maupun kolegannya, yang dapat mendukung kesuksesan kerjanya tidak sombong. Yang penting dalam masalah ini adalah mengembangkan sikap kebawah berupa suka membimbing, seperti kita kenal di Indonesia pernah mengenal adanya jabatan pamong praja, dimaksudkan bahwa diharap didalam diri sang pemimpin terdapat perilaku pemimpin yang senantiasa suka ada niat "ngemong" yang artinya memomomg, mengelola dengan penuh kasih saying. Tetapi biasanya yang tumbuh pada setiap pemimpin yang selalu sukses kemudian menduduki jabatan yang belig tinggi, sikap atau perilaku yang muncul justru adalah perilaku atau sikap "pangreh projo" artinya suka menguasai, suka memerintah, menekan sombong menganggap dirinya selalu besar.

g. Inisiatif

Seorang pemimpin yang ideal harus berinisiatif, sehingga ia akan mampu memutuskan sesuatu dengan benar. Selain itu, ia juga memiliki kemampuan untuk menemukan solusi yang baik untuk kemajuan organisasinya.

h. Lugas

Seorang pemimpin yang ideal harus lugas, sehingga ia akan mampu menjelaskan pikirannya secara langsung dan tanpa bertele-tele. (Sahadi, Taufiq, \& Wardani, 2020). Selain itu, seorang pemimpin harus memiliki kebijaksanaan, kepedulian terhadap kepentingan bersama dan didukung oleh hati nurani yang bersih, tulus dan ikhlas.

\section{SIMPULAN}

Berdasarkan uraian di atas dapat diambil beberapa simpulan sebagai berikut.

1. Pada prinsipnya kepemimpinan (leadership) berkenaan dengan seseorang mempengaruhi perilaku orang lain untuk suatu tujuan.

2. Ada 5 (lima) kategori gaya kepemimpinan yang dapat digunakan seorang pemimpin, yaitu: (1) Tipe Otokratik, (2) Tipe Paternalistik, (3) Tipe Kharismatik, (4) Tipe Laissez-faire, (5) Tipe Demokratik. Berdasarkan ekpiremen melaksanakan kepemimpinan, maka bagi manajemen umumnya, dan bagi kegiatan human relation serta public relations khusunya, yang paling baik adalah kepemimpinan demokratis.

3. Kepemimpinan yang ideal sedikitnya mempunyai 8 (delapan) karekter, ialah : (1) jujur, (2) cerdas, (3) bertanggung jawab, (4) visoiner, (5) adil, (6) disiplin perilaku, (7) inisiatif dan, (8) lugas. 
DAFTAR PUSTAKA

Amirullah. (2015). Kepemimpinan \& kerjasama tim. Jakarta: Mitra Wacana Media.

Arikunto, S. (2006). Prosedur Penelitian (Suatu Pendekatan Praktek). Jakarta: Rineka Cipta.

Dirham. (2019). Gaya Kepemimpinan Yang Efektif. Journal of Islamic Management and Bussines, 2(1), 1-8.

Effendi, O. U. (1993). Human Relation and Public Relations. Bandung: Bandar Maju.

Hakim, A. R., \& Yahya, M. (2014). Analisis Pengaruh Gaya Kepemimpinan, Motivasi Kerja dan Kompensasi terhadap Kinerja Guru. Pendidikan IImu Sosial, 24(1), 6777.

Hasbuan. (2011). Manajemen Sumberdaya Manusia. Jakarta: PT. Bumi Aksara.

Jatmiko. (2013). Pemimpin dan Kepemimpinan Organisasi. Forum IImiah, 10(2), 209219.

Joko, W. (2001). Good Governance. Surabaya: Insan Cendikia.

Kartono, K. (2010). Pemimpin dan Kepemimpinan. Jakarta: PT. Raja Grafindo Perkasa.

Makhfudz, M. (2011). Karekteristik Pemimpin dan Gaya Kepemimpinan untuk Meningkatkan Daya Saing. Prosiding Seminar Nasional Penelitian dan PKMSosial, Ekonomi, Humaniora, 2(1), 505-510.

Rivai, V. (2004). Kepemimpinan dan Perilaku Organisasi. Jakarta: PT. Raja Grafindo Persada.

Sahadi, Taufiq, O. H., \& Wardani, A. K. (2020). Karekter Kepemimpinan Ideal dalam Organisasi. Moderat, 6(3), 513-524.

Stoner, J. A. (1996). Manajemen. Jakarta: PT. Indeks Gramedia Grup.

Veihzal, R. (2003). Kepemimpimnan dan Perilaku Organisasi. Jakarta: PT. Raja Grafindo Persada.

Yuliana, B., \& Widayati, I. A. (2018). Analisis Karakteristik Pemimpin Yang Dikagumi Oleh Bawahan. Jurnal IImiah Administrasi Bisnis dan Inovasi, 2(1), 208-217. 